\title{
Waiting for the Barbarians: Seeking solutions or awaiting answers?
}

\section{Introduction}

Cavafy's (1961) famous poem describes the paralysis induced when waiting for an event that never happens, finding distraction in other things while expecting imminent cataclysm. Libraries have perhaps been guilty of this in recent years, joining the chorus bemoaning the imminent arrival of the digital barbarians and undertaking a whole series of avoidance tactics which make libraries ever more efficient but ever less relevant. Like Cavafy's senators, libraries have prepared themselves, decked themselves in finery but have waited for the future to come to them rather than gone out to engage with it.

\section{The arrival of aliteracy}

Recently, a well known national chain of bookshops stocked perhaps the ultimate symbol of what a post-war baby-boomer and wholly literate generation would see as the final conclusive evidence of dumbing down - a Leonardo Da Vinci action figure. Leonardo Da Vinci, the advertising blurb noted, was the original Renaissance man. He was a master of painting, science, language and (most importantly of all!) the inspiration for Leonardo Di Caprio's name. The website proudly noted that an Einstein action figure would follow. Presumably he would conquer evil with equations. While it is very easy to make the case for this as dumbing down, it is also a marker for the seismic shift which is taking place. There is always inter-generational tension, but we are on the cusp of an era when all the certainties of literacy may well disappear. We are close to a world of aliteracy where reading and writing as generations have known them become optional life style choices rather than the fundamental attributes of a civilised person. Coupled with this is a move from a text based society to an image based society. A whole range of shared cultural reference points relied on words: 
- Doctor Livingstone I presume

- $\quad$ The Charge of the Light Brigade

- Never in the Field of Human Conflict...

- $\quad e=m c^{2}$

- I have a dream

These vaguely remembered phrases and dozens like them carry a raft of meaning and shared values known to everyone, or rather everyone above a certain age. But consider the shared cultural reference points of recent years. Everyone can conjure the images of the fall of the Berlin Wall, of the lone protester in front of the tanks in Tiananmen Square, or of the little girl running naked and screaming down the road in Vietnam. One does not have to be of an age to remember these images at the time when they were created. They are now used repeatedly on film, television and in magazines to represent these cultural reference points. When the tube bombs exploded in the London Underground, the most common reaction was to reach for a cellphone, not to call home, but to take pictures, recording ones part in events. Images rather than words define the new millennium.

Probably the first to note that what we faced was a fundamental discontinuity and not simply the ratcheting up of technology coupled with generational conflict was Marc Prensky (2001, 2001a). It has been almost a decade since he launched the concept of digital natives (the post-www generations) and digital immigrants (everyone else) on the world. His definitions and terms have come in for scrutiny and debate since then, but they are an undeniably powerful metaphor for the change which all too evidently surrounds us. Rather like the debate on climate change, the sheer growing weight of evidence points firmly to the conclusion that Prensky is right. The most important point in his argument is that we are not witnessing a simple speeding up of incremental change but have reached a point of discontinuity marked by fundamental change. Digital natives are, quite simply, different people. 
Prensky's concept can be combined with that of aliteracy. Much less noticed in his writing is the notion that content may itself be in the process of change. A short quotation from his seminal articles shows just how chilling a concept this is:

'It seems to me that after the digital singularity there are now two kinds of content: Legacy content (to borrow the computer term for old systems) and Future content. Legacy content includes reading, writing, arithmetic, logical thinking, understanding the writings and ideas of the past, etc - all of our "traditional" curriculum. It is of course still important, but it is from a different era. Some of it (such as logical thinking) will continue to be important, but some (perhaps like Euclidean geometry) will become less so, as did Latin and Greek. "Future" content is to a large extent, not surprisingly, digital and technological. But while it includes software, hardware, robotics, nanotechnology, genomics, etc, it also includes the ethics, politics, sociology, languages and other things that go with them.'

Quite different from illiteracy, aliteracy applies to those who can read and write, but for whom literacy in the classic sense is an optional extra. On a regular basis newspapers are full of stories of what is seen as dumbing down. Their dyspeptic columnists and correspondents bemoan students who can neither spell, nor punctuate, nor construct a sentence - far less parse one; students wholly reliant on calculators and unable to manage the most basic mental arithmetic, and who use strange abbreviations when txtng frnds. And yet those students communicate perfectly. This could be construed as simple inter-generational grumpiness, but in reality it forms part of the larger discontinuity. Prensky quotes some figures: 
'Today's average college grads have spent less than

5,000 hours of their lives reading, but over 10,000

hours playing video games (not to mention 20,000

hours watching TV). Computer games, email, the

Internet, cell phones and instant messaging are

integral parts of their lives'.

To perceive and regret a drop in standards is quite fundamentally to misunderstand the nature of the change which is taking place.

\section{Instant Results, Instant Gratification and Just Enough}

This new breed of information user doesn't just require that everything be made simple. They have a quite different value structure. On the one hand they want choice, being much less clear that there is right information and wrong information, but at the same time they want selectivity. From creationism to climate change, from the (mis-)use of information to justify political expedience in everything from political expenses to invading Iraq, they do not inhabit a black and white world of right and wrong, but rather one of shades of grey. They want instant results and instant gratification because a fundamental tenet is that convenience trumps quality. They want just enough to complete the task in hand - not complete or perfect. So it has to be cheap, fast and good. Both information and technology have to be mobile and available anytime, any place, anywhere. Such users are not generally inclined to seek advice and help. Quite apart from a working assumption that a Google search will display all known human knowledge, to work through an intermediary requires an input of time and effort which is not seen as commensurate with any benefit. And yet the work by CIBER (2007) clearly shows that such users wildly overestimate their ability to manage information. Students will often give up after their initial searches, assuming they have completed the research process. If it's not on the web, it doesn't exist. Access to full text articles also seems to have changed students' cognitive behaviour, 
although rather depressingly this easier access is accompanied by very short spells of time spent reading the material. Students no longer have to take notes or read through them to develop themes and ideas, an activity central to a focused research project. Electronic articles enable cutting and pasting, almost certainly leading to increased plagiarism, although it may be more than a suspicion that this is usually done from ignorance rather than malice. Research by the CIBER group is unequivocal in its findings, based on huge volumes of log analysis (Nicholas, 2009). The shorter an item is, the more likely it is to be read online. If it is long, users will either read the abstract or squirrel it away for a day when it might not be read (digital osmosis). Users seem to prefer abstracts much of the time, even when given the choice of full text. In short they go online to avoid reading. (Nicholas, 2009)

\section{Adapting to the natives}

If this view of an emerging breed of digital natives is correct, it should quite fundamentally affect how librarians approach the changing environment. Social networking tools can then be seen not as yet more technology to which we must respond, with institutional Facebook accounts and local Twitter managers, but as a manifestation of how digital natives manage their world. The dangers and opportunities do not lie in new systems or in social networking but in understanding what has happened as students and scholars move rapidly into the virtual scholarly space. Above all they want speed and simplicity. Advanced search tools are largely ignored. (Nicholas, 2009). The Gartner Group's hype cycle tool for analysing new technologies clearly demonstrates the need to address underlying issues not current fads and shows how the hype cycle is at present reflected in the virtual learning and web 2.0 area. (Gartner, 2009).

More and more we must expect to inhabit a world shorn of its certainties and in which even information is very often ephemeral. We already have a situation in which $44 \%$ of websites disappear within a year - and sadly this applies just as 
much to longstanding national institutions and libraries as it does to the transitory interests of those in student halls of residence. The 404 Error Message is an all too familiar one. It is a world in which much content is both user created and image based and where Wikipedia, not Britannica, will be the normal entry point to information. There is a curious paradox in hackles rising at the thought of the expert being replaced by the wisdom of crowds, thereby making information democratic rather than authoritative. The foundation of science is that any experiment can be replicated, thus validating it, making science at least nominally consensual and democratic.

\section{Managing, not just storing information}

Perhaps the most effective response for libraries is to work with the grain. For example, the Bodleian Library at Oxford University recently found an entry on Wikipedia describing one of its South American manuscript treasures, the Codex Mendoza. The entry was wrong. Rather than complain or have the entry withdrawn, the Library simply had its staff correct it. That is much the most effective response. (Thomas, 2008). The British Library has done the same to correct an urban myth concerning version control of the bible. (Ainsley, 2009). These small examples point perhaps to a more aggressive attitude to considering how we can manage information and access to it and not simply store it. There is no point in bemoaning the failure to use "proper" resources. The market has decided.

A recognised gap in a web-based information world is trust metrics. A curious by-product of our professional past is that librarians are trusted as impartial, even-handed and good at getting appropriate information. This provides an obvious building block where resources validated by librarians or quality assured on websites will become preferred sources. The very Ranganathan (1931)-like concept of the right information to the right user at the right time becomes a perfect response to this discontinuity. 


\section{Born Digital Content}

It is a curiosity of the library profession in the last ten years or so that it has significantly failed to engage with the e-resources produced by our institutions. Rather than manage this burgeoning and difficult to organise material we have as a profession been obsessed with negotiating licences for commercial material and with digitising the collections we already possess, creating cabinets of curiosities rather than setting out our skills to deal with and take responsibility for managing corporate assets. It has been calculated that the worldwide annual growth in digital data will rise from 161 exabytes $^{1}$ in 2006 to 988 exabytes in 2010, in other words a six fold growth in five years. Yet no one appears to be dealing with this coherently at corporate level (Ganz, 2008). Universities are part of this trend and yet it is doubtful if any university has any idea of what its annual digital outputs are, far less has a collection and curation policy for them. It is probable that all e-outputs are managed by someone, but typically in a wholly un-coordinated way, with no single point of knowledge, standards, advice and monitoring, which is the minimum one might expect. Librarians do not seem to be asserting their central role in this task. Nor is it evident that any university library has a collection policy for the earchives of poets, politicians or physicists which are already at risk. A wonderful example of what we could be doing is the University of Texas Human Rights Initiative (Heath, 2009). It has a clear set of priorities:

* Bulk harvesting of human rights sites from the WWW

* Custom harvesting of human rights themes from Internet

* Preservation and disclosure of born-digital documentation It applies archival principles ranging from selection to dark archiving ${ }^{2}$ of material relevant to outstanding trials, e.g. in Rwanda and it relates the collection quite explicitly to the mission of the institution.

\footnotetext{
${ }^{1}$ Formally an exabyte is a unit of information or computer storage equal to one quintillion bytes. Another way of describing it is that a single exabyte is equivalent to 50,000 years of DVD recordings

2 That is, formally archived but not accessible to the public, generally for copyright reasons.
} 
It is, of course, true that there have been a number of initiatives both locally and nationally to address specific issues varying from the IRI-Scotland project on institutional repositories (Institutional Repository Infrastructure for Scotland, which links academic repositories) to the UK Research Data Service which set out to developing and maintain a national shared digital research data service for the UK Higher Education sector, but these are fragmented and problem specific rather than offering any generic or philosophical approach to the future management of born digital collections

\section{Aggregation of Resources}

Libraries are at their best when they collaborate and aggregate. Librarianship has a proud record of international standards setting from Dewey to Dublin Core, of co-operation through such groups as OCLC and through international services such as inter-lending. Each of these has required a degree of willingness to work together which is neither self-evidently natural nor without significant collective work being required on standards. The same kind of activity will be needed in the development of e-collections - the electronic equivalent of rare books and special collections. Once all commercial material is available through Google, our unique selling point in terms of our collections will lie in the non-commercial born digital material we acquire or that our organisations create. We then need to aggregate and add value to these electronic resources, to provide bibliographic security as well as metadata and to add value by linking to the collections of other libraries. Good if historic examples of this adding value can be seen in the bringing together of the various scattered parts of the Codex Siniaticus (British Library, 2009) or in the Emory University Slave Records project which links the records of the Atlantic slave trade from many archives (Emory University, 2009).

\section{Academic partners not servants}

Throughout this author's career many graduation ceremonies have been attended and always on principle. Two beliefs lie behind that principle. The 
first and most straightforward belief is that the graduates are as much the library's as the department's; they represent the fruits of our labours too. Our value may be minor compared with that of a tutor but it is none the less real and should be celebrated. The second belief is that it does no harm to remind academic colleagues who process through graduation halls that we too are part of the academic enterprise. Sadly, the number of library colleagues in any institution who seem to share these beliefs can be counted on the proverbial fingers of one hand. To detach us from the outcomes of teaching is to diminish us in what we do.

Related to this and perhaps more important is the perception of a change which rests on the way in which libraries and librarians have shifted from being academic partners to academic servants (Law, 2009). Historically the librarian was one of the three named officers of the university and seen as a participant in the academic process, albeit a minor one. Then libraries grew in size, staffing and budget and the librarian became much more managerial and much less academic. We slowly elided into that amorphous group of service providers ranging from human resources to estates. Libraries have never been better managed but we are increasingly servants not partners in the academic process. That is ground which needs to be reclaimed

\section{Teaching and Learning}

Some depressing statistics come from a recent OCLC (2006) survey which showed that:

- $89 \%$ of students use search engines to begin a search

- $2 \%$ use a library web site

- $93 \%$ are satisfied or very satisfied with this approach to searching

- $84 \%$ are satisfied if librarian assisted.

One explanation for this reduction in satisfaction when librarians try to help is the so-called "eat spinach syndrome". Thus when a student wants a quick fact or a short cut or the answer, library staff insist on showing them how to 
undertake the task properly. Do it properly or not at all; eat your spinach, it's good for you. Worthy as such an approach is, it is clearly not what the market wants and we have to devote much more effort to meeting user needs not handing on traditions of competence - or indeed hanging on to traditions of competence. We have huge potential to be real partners in the teaching and learning process, but this will require a fundamental rethinking and refashioning of the concept of user support. For example: managing the collections of learning objects; managing and preserving the wiki and blog spaces; managing the content links and licensing. These are all well within existing library competences.

\section{Information literacy}

Libraries have a good record in dealing with information literacy for students and this should be built on. The ineptitude of students in this area is clearly understood and recorded (CIBER, 2007). Information literacies, including searching, retrieving, critically evaluating information from a range of appropriate sources and also attributing it - represent a significant and growing deficit area (Hughes, 2009). This student ineptitude is matched by two less well understood areas. The first is making the technology work effectively. The need to train and enthuse academic staff is understood but all too rarely addressed and even where pockets of excellence exist, translating best practice across disciplines within an institution is a Sisyphean task. Even where the issue is addressed it tends to be seen in terms of supporting academic staff in the use of teaching applications. And yet the information literacy skills of academic staff are just as much in need of upgrading. There is a huge area of exploration and innovation to be undertaken in everything from reference management to social networking for research; in the use of tools and applications ranging from delicious to Openwetware. The second area is making the technology work. New technology for teaching and learning is a major investment for an institution and there is a tendency to manage acquisition but not maintenance. Under-resourcing everything from technicians 
to projector bulbs is an understandable but misguided option. The library often has a clearly understood role as the leader in developing information literacy for students and it is then a realistic aspiration to broaden and extend this role to engage much more with developing the information literacy of academic staff and ensuring that the library at least has reliable and well provided teaching spaces where information literacy skills can be developed.

\section{Staffing}

But it is not enough to identify the issues which we are neglecting and the issues to be addressed. The ability of library staff to deal with these has to be considered. Thus library staff skills are key. Corrall, (2009) rightly argues that professional boundaries are continually evolving and that our professional competency needs continue to be multi-faceted, with demand for both a breadth and depth of expertise. She suggests that Library and Information Science (LIS) organisations can build capacity through recruitment, development and/or partnership; that job design, project working and systematic reflection can contribute significantly to workplace learning; and that academics and practitioners can both benefit from collaborative partnerships in education and research. There is a need to address the underlying implications of this seismic shift into social networking and beyond. There is little point in encouraging individual members of staff to invest in specific but transient technologies whether Second Life or Moodle, without a clearer philosophical view of what the library is trying to achieve. Yet all of this is happening at a time when LIS education is in steady decline. The number of Library Schools, certainly in the United Kingdom and the United States is diminishing and a recent study (King, 2009) has shown that Insufficient graduates are being produced in the United States to meet the needs of libraries. Quite apart from the reduction in the number of graduates there are questions over the relevance of the curricula. To be fair this is a hoary old area of controversy rather than a new development. CILIP has attempted to address the issue by considering making Continuous Professional Development (CPD) a 
requirement for CILIP members. Some institutions require or at least encourage staff to undertake post-appointment qualifications, ranging from professional qualifications to training in teaching and learning. There is a real need for a much wider professional debate on how skill sets achieved at the start of one's career are to be refreshed, extended and developed as a routine part of professional life.

\section{Conclusion}

It is all too easy to see the prospect of an aliterate world in apocalyptic professional terms. Much better to recognise that repurposing our skills, particularly in the areas of building collections of born digital materials, providing trust metrics and kitemarking, teaching information literacy skills and acting as a partner in the academic enterprise will be more prized than ever. The trick will be to ensure that our profession responds to this, rather than abandoning the field to others while we guard the gates of our paper based storehouses of knowledge. The French politician, Alexandre Auguste LedruRollin's perceptive comment on leadership that "Ah well! I am their leader, I really ought to follow them! " is absolutely pertinent. In the developing world the market will decide what is useful valid and relevant. However, it would be fatal to follow Cavafy's senators and assume we know what the market wants. Determining what the market wants and then providing it will be a key component of building relevant and appropriate services. Good practice exists in pockets in this (McKnight, 2008) as in everything described above. We must discover what our customers want and then build on that, rather than attempting to lead them towards a future which they find irrelevant.

\section{References}

Ainsley, Rob (2009) Great Arse. Letter in the London Review of Books Vol 31 no 15, 6 August British Library (2009) http://publishing.bl.uk/book/codex-sinaiticus 
Cavafy, C. (1961) The Complete Poems of Cavafy, translated by Rae Dalven, New York:

Harcourt, Brace \& World

CIBER (2007) Information Behaviour of the Researcher of the Future. London: CIBER, 2007.

http://www.bl.uk/news/pdf/googlegen.pdf

Corrall, S. (2009) Hybrid Roles and Blended Professionals. What competencies are needed?

How can they be acquired? Unpublished paper given at the SCONUL 2009 Conference,

Bournemouth

Emory University (2009) The Trans-Atlantic Slave Trade Database Project

http://metascholar.org/TASTD-Voyages/

Ganz, J. (2008) The diverse and exploding Digital Universe

http://www.emc.com/collateral/analyst-reports/diverse-exploding-digital-universe.pdf

Gartner (2009). Gartner's Hype Cycle Special Report for 2009

http:// www.gartner.com/DisplayDocument?ref=g_search\&id=1108412\&subref=simplesearch

[this important report is usefully analysed in Jane Hart's blog, Social Media In Learning http://janeknight.typepad.com/socialmedia/2009/08/the-gartner-hype-cycle-2009.html ]

Heath, F. (2009) Human Rights: The Challenge of Documentation in the Digital Age

11th Fiesole Collection Development Retreat [Website in preparation at

digital.casalini.it/retreat/retreat_2007.html]

Hughes, A. (2009) Higher Education in a Web 2.0 World

http://www.jisc.ac.uk/publications/documents/heweb2.aspx

King, D. (2009) Facing up to the economic realities: Placing a bet on the future. Unpublished paper from the 2009 SCONUL Conference, Bournemouth

Law, Derek (2009) The Changing Roles and Identities of Library and Information Services Staff in Whitchurch, C. \& Gordon, G. Academic and Professional Identities in Higher Education: The Challenges of a Diversifying Workforce. London, Routledge

McKnight, S. (2008) Improving Customer Satisfaction: Changes as a Result of Customer Value Discovery Evidence Based Library and Information Practice, Vol. 3:1 pp33-52

Nicholas, D. (2009) What is beyond books and journals? Pointers from CIBER's Virtual Scholar programme. Third Bloomsbury Conference on e-publishing and e-publications, 25 \& 26 June 2009. Beyond Books and Journals http://www.ucl.ac.uk/infostudies/epublishing/e-publishing2009/

OCLC (2006) College Students' Perceptions of Libraries and Information Resources: A Report to the OCLC Membership. Dublin, OH: OCLC, 2006.

Prensky, Marc (2001) Digital Natives, Digital Immigrants On the Horizon Vol. 9 No. 5, pp1-6

Prensky, Marc (2001a) Digital Natives, Digital Immigrants Part 2: Do they really think differently? On the Horizon Vol. 9 No. 6, pp1-6

Ranganathan, S. R. (1931) The Five Laws of Library Science. Madras Library Association (Madras, India) and Edward Goldston (London, UK) 
Thomas, S. (2008) l've looked at life from both sides now. Paper given at the $10^{\text {th }}$ Fiesole Collection Development Retreat, Fiesole http://digital.casalini.it/retreat/2008_docs/thomas.pdf 